\title{
IDENTITY, GENDER AND SPACE IN ANNE ENRIGHT'S NOVELS
}

\author{
Raximova Umida Saliyevna \\ Assistant Teacher of Philology faculty, The Department of English Languages and Literature, \\ Urgench State University, Uzbekistan \\ Independent Researcher of Uzbekistan State World languages University, Uzbekistan
}

\begin{abstract}
To demonstrate the writer's skill in creating the image of the mother in Anne Enright's novels, we studied the opinions of a number of foreign scholars and writers. First we studied their attitude to Enright. In this article, we will look at some of her remarkable works.
\end{abstract}

Keywords: literature, image of the mother, novels, scholars, writers, motherhood, The Gathering.

\section{Introduction}

Enright has lots of notable novels as What Are You Like? (2000), an Irish Writer Award-winning autobiographical work Making Babies: Stumbling into Motherhood (2004); the Man Booker Prize The Gathering (2007) and the Irish Art Award-winning The Green Road (2015) .

Enright often focuses on the subject of motherhood in his writings, and believes that the difference between the existence of motherhood and the image of perfection in Ireland must be due to the lack of discussion on the subject in everyday speech. In an interview with Caitriona Moloney, she says: "I am very interested in the image of a mother depicted in Irish literature because men can't actually write them. They (mothers) are very often dead, or left of the narrative. The mother gets half a sentence and there is an awful lot about fathers." 1

\section{Literature review}

Indeed, Enright describes in her works the mother in a dead, hidden, silent state. For example, the author in What are you like? tried to describe the gap between the deceased mother and her two twin daughters in her work. It was seen as a transition period because it was marked by putting together the birth and death of a pregnant mother who had died for the lives of her children. Critic Ann Mulhall says: "[t]he mother is the unspeakable phantom, the gap enclaved within the novel's genealogy. Enright works to make this absence present, to answer to its uncanny insistence and, in some cases literally, to enable the ghost to speak.." 2 In her works, Enright demonstrates her deep concern for how feminine elegance is portrayed in modern Irish literature, and her aims to dismantle the perfect, virgin, and pure ideal of the Irish woman. In his novels, Enright portrays the mother in a variety of ways: in quiet, pregnant, and empty situations, gender issues, as well as family, caring, guilt, and patient resilience. In this article, we will consider how the various features of the mother listed above are skillfully reflected in the author's works.

\section{Analysis}

${ }^{1}$ Caitriona Moloney, "Anne Enright Interviewed by Caitriona Moloney", in Irish Women Writers Speak Out: Voices from the Field. Edited by Caitriona Moloney and Helen Thompson (Syracuse, NY: Syracuse University Press, 2003), p61.

${ }^{2}$ MULHALL, Anne. 'Now the blood is in the room': The spectral femininein the work of Anne Enright.' In: Anne Enright. Edited by Claire Bracken and Susan CahillIrish Academic Press Dublin. Portland,OR, 2011, p68-69. 
According to Laura Sidora, the image of silent mother's state in The Gathering, Enright criticizes the inability of modern Irish women to re-establish themselves in the midst of an insecure, silent, patriarchal past by placing her protagonist Veronica Hegarty in "new Ireland". On the eve of her disappearance, Veronica throws her past in order to reveal political, social, and family factors that led to the silence of Irish women over her brother's suicide, and thus regain her subjectivity, rewriting her history. At the same time, this work sheds light on the spectrum of femininity that materializes the real conditions of women and chronicles motherhood within the ultimate national story that follows the state story ${ }^{3}$. Laura Camille said, "Women have had to struggle to gain the right to an authentic identity, rather than conforming to the pressures of a society that oppresses them" ${ }^{4}$. Veronica, as a representative of a view of oppressed Ireland in the novel, demonstrates the struggle to restore and reconsider the social roles of Ireland after its decolonization.

The reason for the colonial rule was that family history and customs in Ireland were devalued, and for a newly liberated Ireland, the roles of the family, and especially women, in the family had to be restored. In The Gathering, Enright reveals that mothers, women and wives in the family have a place, not limited to being housewives. Through the novel, Enright portrays the state of the mother in any situation, a silent mother who does not leave the family, patient and resistant to the death of her child.

Enright reveals pregnancy, changes in a woman's body and brain, and feelings of motherhood in Making Babies: Stumbling into Motherhood. In writer's novels, we can observe the depiction of mothers at different times and in different images. In Making Babies: Stumbling into Motherhood, Enright presents her thoughts on how she became a daughter, a writer, and a mother in her autobiographic novel.

In the following passage, she reveals the difference between the generations on the issue of motherhood and emphasizes herself as a modern woman who was brought up by women in other times. Enright says:

I was reared in the seventies, by a woman who had been reared in the thirties, and we were both agreed that getting pregnant was the worst thing that could happen to a girl. My mother thought it would ruin my marriage prospects and I thought it would ruin my career prospects (same thing, really, by the different lights of our times). And when do you stop being a girl? By 'career' I meant something more than salary. I could not get pregnant, I thought, until I had 'gotten somewhere', until I 'knew who I was', until I was, in some way, more thoroughly myself. (ENRIGHT 2005, p.13).

Caroline said, "The stories suggested by Anne Enright are fascinating because of their ingenuity." Caroline added, "Enright's work is not limited to mothers. Instead, they deliberately used an inappropriate perspective to expose a stage in a pregnant woman's life that is not typically demonstrated in the literature. To this end, they emphasize the path from the outside world to the inside of a woman, both physically and emotionally", Taking

\footnotetext{
${ }^{3}$ Laura Sydora. "Everyone wants a bit of me": Historicizing Motherhood in Anne Enright's The Gathering. Women's Studies: An interdisciplinary journal. Laura Sydora. University of Alberta, Canada 2015, p239

${ }^{4}$ Laura Camille Brownell. "TO SWEETEN IRELAND'S WRONG”: THE PRESENCE OF POSTCOLONIAL TRAUMA IN CONTEMPORARY IRISH FICTION B.A., California State University, Sacramento, 2007, p32

${ }^{5}$ Eufrausino, Caroline The Spiraling Aesthetics in Anne Enright's Work/Caroline Eufrausino. Sao Paulo,2017.p22-42.
} 
as an example, her novel "Making Babies", which features a woman who born and raised in Ireland during the conservative and misogynistic periods. This autobiographical note by Enright is written in a sharp and ironic tone, and it clearly criticizes the Catholic Church's pressure on women, especially those who are pregnant and have power over their own bodies. In this passage, Enright tells his mother that "a woman raised in the thirties brought me up in the seventies" and mentions that their worldviews were two different things. She said her mother was afraid of getting pregnant before she got married and that she was afraid of getting pregnant before she could find a suitable job because in those years it was difficult for a young woman to find a job to have children. In Ireland and other European countries, the question is whether families are ready to take care of a child before they have children. However, when Enright extolls all the wonders of being a mother of two loving children at the same time, as well as sharing family and cultural fears and motherly concerns, resentment arises. Moreover, this is not explained by the realization of all the happiness they can bring after their birth and their subsequent fear, but rather reveals in her story that she loves motherhood at the same time, even though she sees motherhood as an eternal nightmare. She also concludes the passage by mentioning her uncertainties about personality formation: "until I 'knew who I was', until I was, in some way, more thoroughly myself". In this way, Enright demonstrates that before becoming pregnant, it is important for her to have a good understanding of herself and to pursue career prospects. So, the writer shows that before becoming a pregnant and having a child, a woman must be mature in all respects and take her place in society.

In Making Babies, the author also discusses gender issues, the role of mothers and fathers, We know that from time immemorial, women in the private sector have been considered responsible for taking care of children, feeding, bathing, nurturing and educating them, and have always been entrusted to mothers. The role of mothers in child rearing is enormous. In this sense, Making Babies not only contextualizes the Irish society to which he refers, but also the views of the women in that society. As Enright points out:

Mothers worry. Fathers worry too, of course. But mothers are supposed to worry, and fathers are supposed to reassure. Is it really a gender thing? Maybe the people who worry most are the ones who spend the most time with the baby, because babies train us into it - the desperation of holding, walking, singing, distracting. (Enright 2005, 177).

Through this passage, Enright demonstrated the role of women and men in gender issues, the role of forced motherhood as a woman. She says that mothers should "are supposed to worry" that this is expected of women and is part of their gender performance. Enright described any attitude that deviated from a mother's normal behavior as unnatural, a criticism of a mother who does not care for her children.

In The Gathering there is also a passage that reflects the narrator Veronica's wife, Tom, and her responsibilities in the family and community. Much of the controversy in Veronica's marriage stems from the fact that trust is nothing more than neutral or static. Genderization of economic roles in modern Ireland means that Tom is constantly changing the credibility parameters for Veronica.

When Tom was starting out in his own business, and I had a small baby, I left that baby with a minder and worked day and night to keep up with the mortgage repayments. But when he began earning again, it was clear that his money was much more important than any money I might earn, that his job was an important job, that he couldn't be expected to be doing pick-ups and Pampers and snot and drop-offs with so much importance around. And, eventually, I gave up work so that we 
would not be so much in his way. (Gathering 151)

Here, Veronica realizes the importance of her husband Tom's work and the money she earns from her money, as well as her role as a babysitter, next to her little baby around the family, and gives up the job she worked day and night to pay off household debts. Now she realized that her husband's money was more valuable than hers and that she would resign so as not to interfere with Tom's work on the housework trips. When convenient, Tom takes on the role of Veronica's caregiver as a mother at home. Similarly, in a historically independent nation-state, there was sometimes a lack of mutual trust in the status of women as citizens, and gender-based working roles made Veronica uncertain. Getting a work permit when needed encourages Veronica to exist in Irish society, eventually returning to her motherly and family responsibilities. The qualities that Tom Veronica gives for her work reflect the skill she puts into her memories of the past. While Veronica's character reflects clear achievements in Irish society, new femininity, it also implies long-term gender inequality that threatens feminist achievements.

Enright develops this by describing Veronica's struggle for reconciliation with her mother as well as her own as a wife and a mother. Concerning the image of the mother in The Gathering novel, Carol Dell Amico says: "The mother is a caricature of the prolific breeder of Ireland's past, having borne eleven children and suffered a few miscarriages. Veronica's mother is a symbol of the spotty presence of Irish women in the nation's historical record ${ }^{6,}$.

Indeed, in the novel, the mother is likened to a child-producing machine, but a lifeless object that is out of order because of it. Veronica acknowledges in part how patriarchal structures influenced her mother's negligence and neglect. Although the novel never seeks complete reconciliation between mother and daughter, the variations between different story layers help to contextualize Veronica's mother's behavior within the state models of the sacred family.

\section{Conclusion}

In short, The Gathering accepts the worldview of a girl who is already a mother, and thus the novel is not a rejection of motherhood, but a compromise of negotiation, partnership, and silence, and "attenuation," that the girl/mother should symbolically accept as her place. In The Gathering, the mother's voice is allowed to speak more subtly but hopefully: the novel is characterized by constant appeals to the body, so even the most abstract concepts, such as death, love, or history, are conveyed through intense body images reflecting the semiotic space of motherhood. When asked about motherhood and language, Enright said, "All languages occur between us and our mothers, so it is impossible to write about mothers" (Anne Enright, Cartagena, 2008). What I find important in this article is that, as the novels describe, it is not about its ending, but rather the fact that it is the mother, not the father, that is situated at the origins of the language.

\section{References:}

1. Caitriona Moloney, "Anne Enright Interviewed by Caitriona Moloney”, in Irish Women Writers Speak Out :Voices from the Field .Edited by Caitriona Moloney and Helen Thompson )Syracuse ,NY :Syracuse University Press ,2003(, p61.

2. MULHALL, Anne. 'Now the blood is in the room':The spectral feminine in the work of Anne Enright.' In: Anne Enright. Edited by Claire Bracken and Susan CahillIrish Academic

\footnotetext{
${ }^{6}$ Carol Dell' Amico. Anne Enright's “The Gathering”: Trauma, Testimony, Memory. New Hibernia Review / Iris Éireannach Nua, FÓMHAR / AUTUMN 2010, Vol. 14, No. 3, p70.
} 
Press Dublin.Portland,OR, 2011, p68-69.

3. Laura Sydora. "Everyone wants a bit of me": Historicizing Motherhood in Anne Enright's The Gathering. Women's Studies: An interdisciplinary journal. Laura Sydora. University of Alberta, Canada 2015, p239

4. Laura Camille Brownell. "TO SWEETEN IRELAND'S WRONG": THE PRESENCE OF POSTCOLONIAL TRAUMA IN CONTEMPORARY IRISH FICTION B.A., California State University, Sacramento, 2007, p32

5. Eufrausino, Caroline The Spiraling Aesthetics in Anne Enright's Work /Caroline Eufrausino. Sao Paulo, 2017.p22-42.

6. Carol Dell' Amico. Anne Enright's “The Gathering": Trauma, Testimony, Memory. New Hibernia Review / Iris Éireannach Nua, FÓMHAR / AUTUMN 2010, Vol. 14, No. 3, p70. 1MULHALL, Anne. 'Now the blood is in the room':The spectral feminine in the work of Anne Enright.' In: Anne Enright. Edited by Claire Bracken and Susan Cahill Irish Academic Press Dublin.Portland,OR, 2011, p69.

7. ESTÉVEZ-SAÁ, Margarita. A Map of Things Known and Lost in Anne Enright's The Green Road. In: Estudios Irlandeses. Number 11, 2016, p. 47

8. Cahill, Susan.Irish Literature in the Celtic Tiger Years 1990-2008: Gender, Bodies, Memory. New York: Continuum International Publishing Group, 2011. Print,p180.

9. Eufrausino, Caroline The Spiraling Aesthetics in Anne Enright's Work/Caroline Eufrausino. Sao Paulo, 2017.p49

10. CUMMINS, Anthony. The Green Road by Anne Enright, Review: 'virtuosic'.The Telegraph. Telegraph Media Group, Acesso em: 29 de julho de 2015.

11. Eufrausino, Caroline The Spiraling Aesthetics in Anne Enright's Work /Caroline Eufrausino. Sao Paulo, 2017.p168

12. Laura Sydora. "Everyone wants a bit of me": Historicizing Motherhood in Anne Enright's The Gathering. Women's Studies: An interdisciplinary journal. Laura Sydora. University of Alberta, Canada 2015, p247

13. Enright, Anne. The Gathering. Black Cat, 2007, p213

14. Laura Sydora. "Everyone wants a bit of me": Historicizing Motherhood in Anne Enright's The Gathering. Women's Studies: An interdisciplinary journal. Laura Sydora. University of Alberta, Canada 2015, p248

15. O'Callaghan, Margaret. "Women and Politics in Independent Ireland, 1921-1968."The Field Day Anthology of Irish Writing Vol. IV and V: Irish Women's Writing and Traditions. Eds. Angela Bourke et al. Cork, Ireland: Cork UP, 2002. 120-176. Print 